\title{
IEIIS AIII REPORIS
}

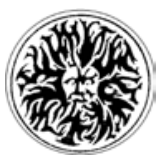

\section{9th JACT Latin Summer School - 2019 Director's Report}

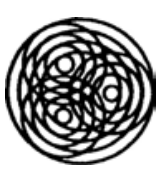

\section{by David Stephenson}

\begin{abstract}
Attending Latin Camp this year has been an invaluable experience which has enabled me to progress in the Latin language more than I had ever thought possible and to make friends for life from all over the world. The teaching is of a superb quality and my teacher was always willing to belp.
\end{abstract}

(Sophia Kerrigan-Noble, beginners' group)

The $39^{\text {th }}$ Latin summer school, our $4^{\text {th }}$ biggest ever, once again took place at Wells Cathedral School, Somerset. Our traditional spread of ages has been even more pronounced (14-59) this year and we have been rather older overall with $38 \%$ of our students hailing from universities or the "real" world. Well over a third of our school-age students were from the state sector and we continue to offer as much financial support as we can, with 12 bursaries given this Summer worth nearly $f, 4000$.

We have also become rather more international, seeing a marked increase from c. $10 \%$ to c. $19 \%$ (easily our highest ever) of students coming from overseas, hailing from countries including Turkey, the Czech Republic, America, Germany, France, Italy,
Norway, Zimbabwe, Holland and Romania. There were even overtures for a student to come from Freetown in Sierra Leone - where it was truly heart-warming to learn of a Latin initiative underway - on a full bursary; unfortunately visas did not work out but we are fighting hard to set it up now for Summer 2020. (It was however my great pleasure to make his school a charitable donation of textbooks this summer.)

\section{Staff and Teaching}

\begin{abstract}
The lessons of the course (as well as the additional lectures and field trips) were very engaging and even though people came from different backgrounds and had had different experience with Latin, the organisers did everything to make the course accessible and well-suited for everyone.
\end{abstract}

(Vratislav Vokurka, student from the Czech Republic)

This has been a year of significant change. Alex Boyt, after ten fantastic years as co-director (and several before that as a tutor, and a good few before that as a student!), resigned earlier in the year; her devotion, creativity and hard work could not have been more missed this summer. I took the opportunity to review the leadership structure of the Summer School and created two assistant director positions, one to run the academic side of things and one with oversight of student welfare, dealing with any issues which arose with individuals and leaving me free to focus on the overall logistics of the operation. After much reflection I asked Dick Mowbray and Sophia Ridley respectively to perform these roles.

I was pleased to welcome back Mish Bancroft, Lindsey Cullen, Clemmie Faulkner, Katie Lathan and Laura Snook. It is important to mix the old with the new and we certainly had a great injection of new blood this summer - Naomi Bradshaw, Dom Jones, Alice Kirrage and Tarika Sullivan all fitted fantastically into the spirit of "Latin Camp!" We also had a new director's assistant, Johnny Boyd, who is currently studying at Oxford.
Please look on the website under "our courses" for details on any of the courses we offer. Once again we had groups from complete beginners tackling the traditional and totally uncompromising So You Really Want to Learn Latin course aiming to cover all the essential grammar of current GCSE specifications and sit an actual past language paper at the end, to GCSE students who mainly focused on readers and other selections of the finest extant Roman literature reading more widely than they would have time for in school, to A Level students reading rather more demanding and "left field" texts (such as Lucan 7) which they are highly unlikely to have met before to provide themselves with that edge for university applications. We were also able to cater for various "disparate" groups who did not fit in obviously to any of these categories.

We are halfway through and I am already feeling more confident in my translations. The time used both in and outside class is proving invaluable to the way I now approach translations. Reading a variety of Roman authors such as Tacitus and Horace has also allowed me to build my own bank of vocabulary which I had not previously seen before.

(Cathryn Barton, advanced group)

We have also been welcoming increasing numbers of students who are about to embark upon a PGCE or are indeed already working in a school without much Latin teaching experience; some of these come to us in order to improve on their own Latin if they were not fortunate enough to have started it at school, others are already fairly strong in the language and we focus more on the teaching side; we try to have more than one group, split on that basis, but all groups will have common elements - a whistlestop fortnight of what we consider the "bread and butter" of how Latin is taught in schools and examined at GCSE and A Level, as well as reading and various work on current set texts. (Translating but also considering literary features and themes.) Needless to say it will always be the more experienced among the tutors delivering this course. 
I am very keen for us to keep developing it as a real contribution we can make to UK Classics teaching and intend to make it a priority over the coming years, continuing the process in consultation with the PGCE course leaders.

I have been teaching MFL for over 30 years but as a novice Latin teacher with no formal training and only a couple of years' experience, I found the introductions to the CLC course and the tips for teaching Latin forpublic examinations extremely useful supremely practical and accompanied by a wealth of examples. The discussion of pedagogy and illustration of class-based techniques were delivered by a widely experienced, insightful and supportive professional who was an enthusiast for his subject and who took obvious delight in passing on his expertise to those who shared his Classics calling.

The pace of delivery, the sense of humour and the systematic approach training were a delight to work with. The tutor was inclusive in manner, jocular but businesslike, well informed without being distant, and wonderfully honest and un-PC in his forthright opinions - encouraging a realistically reflective approach to issues around the most effective ways of teaching Classics.

I can honestly say that in 35 years of teaching, with its attendant hours of often irrelevant and unproductive INSET sessions, this training has provided me with the most practical pedagogical support and useful resources, as well as the most confidence subsequently to draw up schemes of work, plan productive lessons and generally be an effective teacher. It was frequently challenging, but also upbuilding, and always - to use the Director's own phrase - "geeky fun."

(Michael Wager, teachers' group)

We had the usual array of grammar clinics - "regular" aimed at students in the GCSE range and "advanced" for students already in the middle of an A Level. We also added a daily drop-in clinic for beginners to consolidate anything covered over the previous few sessions, and one for anyone else who wanted to go through any specific grammar they were unsure about.

\section{Trips and Events}

Alongside my linguistic advancement in the Latin language, I have enjoyed cultivating my broader interests in the classical world through engaging with other students with a wide range of interests and attending the excellent talks given by academics who are experts in their fields.

(Sophia Kerrigan-Noble, beginners' group)

My aim with the lectures is to provide a range of both "mainstream" talks on texts the current students are likely to be studying at school and talks of wider and more general interest. Our speakers certainly made that happen this year. In keeping with tradition, Dr. Anthony Bowen gave the first talk and taught us how to pronounce Latin properly. Once again Prof. Matthew Leigh returned to talk about heroism in Aeneid 11. Prof. Costas Panayotakis has become one of our regular fixtures, this year with a passionate delivery on the literary and contextual allusions in Petronius' story about Trimalchio's dinner party. We widened the repertoire a little this year with the first lecture in quite some time on Roman art delivered by Dr. Shelley Hales with a special focus on how it is used to present emperors. For the final lecture this summer, Elena

Theodorakopoulos delivered a very thorough coverage on love, poetry and friendship in Catullus.

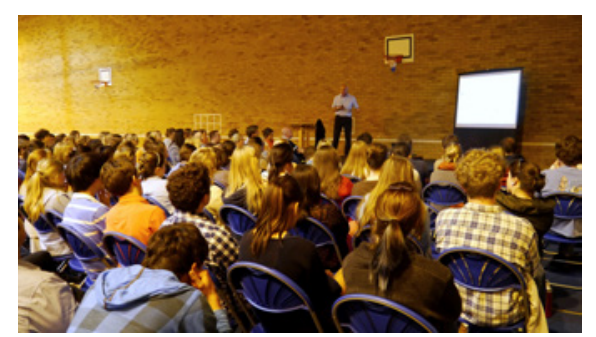

Students enthralled as Stephen Bird delivers his lecture the evening before our Bath trip

We also had two lectures designed to directly complement our trips. On the middle Sunday evening, Dr Ben Kane once again provided us with a fascinating insight into the life of a Roman legionary in south west England. This talk once again provided an opportunity to develop further the understanding gained on the trip that day to the military barracks, bath-house and amphitheatre at Caerleon and Roman town at Caerwent. Stephen Bird prepared us for our trip to the Temple and Bath-house at Aquae Sulis with his talk the evening before (as well as providing a personal welcome to our group when we arrived) and as always his support was vital to the success of the trip itself. The museum at Bath continues to update its exhibitions regularly and Stephen provided us with a great preview of some exciting new developments.

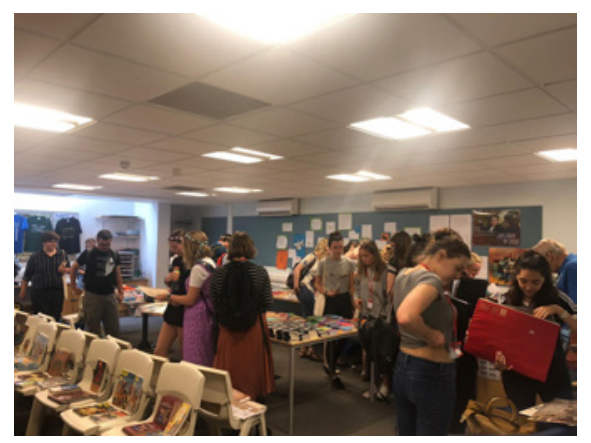

Students exploring the remains of the villa at the Roman town at Caerwent

Other events included a quiz night during the first week, giving the students another opportunity to break the ice and meet people outside of their teaching groups. We ran various Twitter and Instagram "best picture" competitions and there were lots of superb selfies in Wells and shots of the Roman sites on both trips. I was delighted to welcome back the Hellenic Bookservice who did excellent business with our students for the last two full days. We were also lucky to have Dr. Mark Grant back to provide Roman cookery sessions for some of our students.

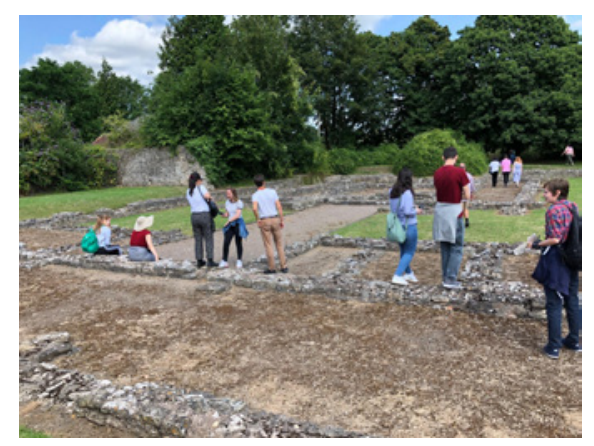

Hellenic Bookservice doing great business with the students 
And, of course, Latin Camp would not be Latin Camp without the play on the last night. After a nice little warm-up singing MacDonaldo est fundus (which after all can only really be appreciated in the original Latin) the students were "treated" to the staff's version of Plautus' miles gloriosus which was essentially a version of A Funny Thing Happened on the Way to the Forum before launching into our Roman costume party. Winners this year included renderings of Ceres, a Vestal Virgin, Neptune and Amphitrite as a pair, Elagabalus (a $3^{\text {rd }}$ century AD emperor - I had to check too) and several students from the teachers' group collectively representing the temple and baths at Aquae Sulis!

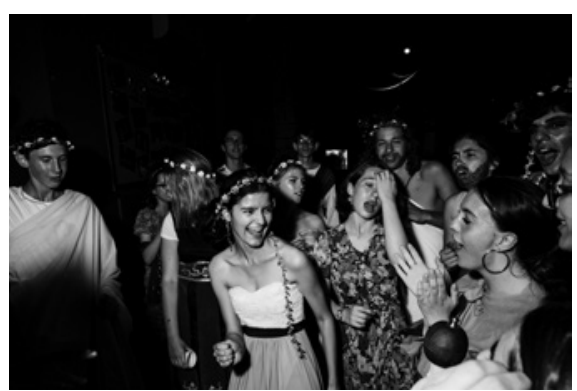

Dancing the night away at the last-night costume party

\section{Looking Ahead}

The other major piece of news is that this summer was our $18^{\text {th }}$ and last summer at Wells. For summer 2019 and beyond we are relocating to Harrogate Ladies' College. This was a very tough decision, not made quickly and not without a thorough investigation and two-day visit. The move should enable me to freeze the fees for at least a couple of years ahead as well as look to promote bursaries more actively for those from less privileged backgrounds. Harrogate is better for U18 students particularly - just as safe with a lot more shops, cinema, theatre, museums etc. and plenty of nice places for the adults to visit in the evening. The Bath trip will be a great loss but York should be good for a day trip and Hadrian's Wall is a realistic prospect for the middle weekend, possibly overnight at a hostel. The accommodation and facilities are at least as good as what we are accustomed to, there are more beds available and we should have the run of the place, at least in the evenings.

Just a very sincere thank you for organising such a wonderful two weeks. Maddy absolutely loved it. She has returned home full of enthusiasm and excitement / Zareen had the time of her life and told me it was the happiest she has ever been!

(By parents on behalf of Zareen Hyatt and Maddy Wainwright, two GCSE students)

\section{Acknowledgement and Thanks}

This year I awarded $£ 3940$ in a total of 12 bursaries and nobody who asked for a bursary was sent away emptyhanded. It is always very important to us that we make the Summer School and the learning of Latin as accessible as possible and we welcome applications from all educational levels and backgrounds.

The sponsorship we are so generously given not only allows us to provide places to those who would not be able to come otherwise but it also helps us keep fees down overall and replenish textbooks, among other ongoing expenses. I would like to thank those sponsors whose generosity helps makes this possible:

- The Classical Association

- Faculty of Classics at the University of Cambridge

- The Craven Committee, University of Oxford

- The Jowett Copyright Trustees

- Trinity College, Cambridge

The success of the summer school is largely reliant on the quality of its students and of its staff. I was nervous about my first summer as the sole director, perhaps understandably but totally unnecessarily. This really was one of the nicest cohorts of students I have ever seen (and I have been coming non-stop since 2002) and not once did anyone appear on my radar over anything negative. The same is true of this year's staff team; I am especially grateful to Dick and Sophia for their immense support throughout but I would welcome any of this year's staff back in a heartbeat - new and old alike gelled together, mucked in and made this one of the most successful Latin Camps ever, working tirelessly to make the experience as good as it can possibly be for the students. I really can't do my job properly without the support of a strong team. As for Johnny, there have been some superb assistants over the years and he was right up there with the very best of them.

Coming to Latin Camp was the best decision I made this year. Not only did I get a chance to brush up my Latin grammar, particularly the verb accidence, and to read Latin literature in the original, but I also had the opportunity to join the "Latin camp" community and spend valuable time with like-minded people of my age.

(Maria Ciocan, student from Romania)

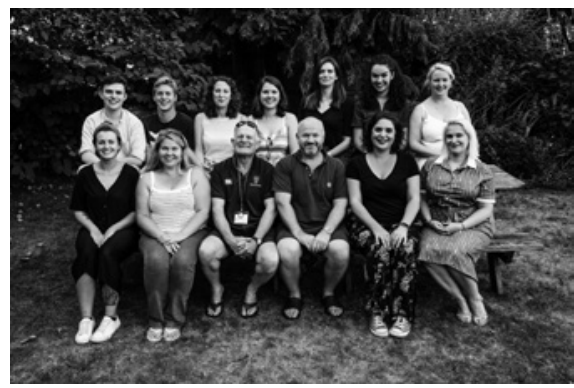

The 2019 Latin Camp staff team

The $40^{\text {th }}$ JACT Latin Summer School will run from Monday $20^{\text {th }}$ July to Saturday $1^{\text {st }}$ August. The website www. latincamp.co.uk continues to be the key source of information and contains a very simple online application form. If you have any questions at all after reading this, please do get in touch on d.stephenson@ warwickschool.org.

David Stephenson, Director JACT

Latin Summer School 